\title{
EVOLVING SECURITY CONCEPTS: THE PREMIUM ON GOVERNANCE IN THE CASE OF BULGARIA
}

\author{
Valeri RATCHEV, Vesselin PETKOV, and Todor TAGAREV
}

\begin{abstract}
The EvoCS project analysed security perceptions and discourses in 12 countries, including Bulgaria. The authors of the Bulgarian case study introduce the particular 'transitional' context of the security discourse, briefly describe the project methodology and present the research results for Bulgaria, along with explanation of the historical and social influences on security perceptions. The Bulgarian security discourse emerged as unique among all twelve examined in EvoCS. It is dominated by the "political stability and security" core value and the overarching theme is governance - in the political, social, and economic spheres, as well as in facing the pervasive threat of corruption. The case study epitomises a double disconnect between the official Bulgarian security discourse and societal perceptions of security challenges, on one hand, and between challenges identified in EU security strategies and challenges faced by Bulgaria, on the other. This is reflected in the final section of the paper, presenting policy recommendations on making the security discourse in Bulgaria more relevant to the challenges the country faces and the societal interests.
\end{abstract}

Keywords: Political stability, social security, corruption, governance, security discourse, Bulgaria.

\section{Introduction}

The paper presents some of the findings on Bulgaria, resultant from the FP7 project "The Evolving Concept of Security: A critical evaluation across four dimensions" (EvoCS) along with recommendations for shaping the future environment in the country for security policy making. The objective of EvoCS is to identify the various European concepts of security, which differ depending on place and time, and to analyse the similarities and differences between them. To achieve this, the project brings together relevant European stakeholders to discuss core values, threats to them, and measures to be taken to protect them. The results of these discussions and analyses are being used to formulate recommendations for changes in the working parameters of various types of security end-users and will serve as guidelines for policy makers who are responsible for formulating measures that influence an evolving European concept of security. 
One of the countries, examined by EvoCS, is Bulgaria. A member of the European Union and NATO, Bulgaria is still often regarded through the prisms of the Balkans' dangerous past and current vulnerabilities and its specific attitude towards Russia. More importantly, Bulgaria still struggles with the profound transformation of its society and economy. This has specific repercussions on how security is being perceived from within the country, with the respective implications for the national and the European security policy-making.

This paper is organised as follows. The next section sets the particular context for examining the perceptions and preferences in shaping security policies, and calls for objective assessment of the perceptions. Such an objective assessment is done in the EvoCS project, and the third section of the paper gives a brief overview of the project and its methodology. The fourth section presents EvoCS research results for Bulgaria and explains the historical and social context of the security discourse in the country. Section five outlines the authors' policy recommendations on making the security discourse in Bulgaria more relevant to the challenges the country faces and the societal interests. We conclude with summing up the study results and discussions.

\section{Bulgaria's Security Discourse}

Squeezed between the heavy burden of the protracted transition from communism and the public demands for a better life, and between the comprehensive Russian aggressiveness and waves of migrants sweeping the country, the current Bulgarian security discourse is dominantly inward focused.

This inward focus derives from the communism-rooted respect to the political power as a sole source of not only national security, but also social stability and personal well-being. As elsewhere in Eastern Europe, the extreme securitisation under the communist regime was managed through uncompromising political control and overwhelming security apparatus. Unlike most other Central and Eastern European countries, the alliance between former communist nomenklatura and security services' figures in Bulgaria dominated the first eight years of transition, leading into a political, economic and social collapse. The bankruptcy of the country in 1990, the financial collapse of 1996, and the corrupt and criminal mass privatisation in-between caused a brutal economic and social shock. Viewed from the inside, the Bulgarian transition is experienced as a failure and betrayal by the elites, whoever they are - 'left' and 'right,' 'old' and 'new.' Many Bulgarians, especially in the older generations, feel as losers in every aspect; the democratic gains seem modest in comparison with social losses and the constant fear of destabilisation. The weaknesses in political governance are reflected mainly in the accumulation of a democratic deficit and a lasting distrust of institutions. ${ }^{2}$ 
The insufficient level of social development is another driver of insecurity. The corrupt and party-driven mass privatisation transferred the collective assets into the private hands of the so-called "unclear subjects" - official term for those business persons whose capital is gained through politically covered actions that could not be defined as violations of the law. ${ }^{3}$ The social diversification became enormous in a very short period of time; it is continuing and will likely last for long. Paradoxically, despite that Bulgaria managed successfully the financial crisis of 2009-13, the GDP expected growth for 2015 is about 2.5 percent, and unemployment is currently under 10 percent, the social status of the Bulgarians continues to be between the lowest in the European Union. While the picture is encouraging percentage-wise, in real terms it is more than disappointing. According to a recent survey of the National Statistics Institute, 40.1 percent of the population is threatened by poverty (in the EU, at $40.2 \%$ this indicator is higher only for Romania). ${ }^{4}$ Successive governments manage poverty as mathematics rather than policy. For example, in 2015 the poverty line ${ }^{5}$ will be "increased" with 17 Euro to reach 143 Euro. The only instrument to make the business pay higher salaries (the average wage is 190 Euro) is the legally defined minimum monthly wage, planned to reach 210 Euro in $2016 .{ }^{6}$ Bulgaria ranks second in the EU according to the risk of poverty or social exclusion of its citizens. Solving the problem of poverty is compounded by the high share of shadow economy, exceeding 32 percent (second largest in the EU). ${ }^{7}$

Corruption continues to thrive due to the loosely defined legal framework for doing business and the ineffective state control. Furthermore, the tenth consecutive report of the Centre for the Study of Democracy is titled "Anti-corruption Policies against State Capture." The manifestations of political corruption have reached alarming proportions and include phenomena like 'vote buying,' control over the media, influence over the judiciary and the security services, etc.

Russia remains a strong factor in the Bulgarian security discourse. Kremlin's influence on the economy, and through it - on the political system and foreign policy of Bulgaria, has been built up during the Cold War and intensively modified during the transition period. The main transmitters of influence are figures from the past that still have positions in several political parties, the armed forces, the diplomatic corps and the security services. The second circle, created to influence the public opinion, includes acquired or bribed media, sponsored foundations, NGOs and academics. The model that works successfully and has been tried in a different context was recently "enriched" by funding small, yet parliamentary-presented parties (which offset the current decline of the Socialist Party), arrogant diplomatic pressure against Bulgaria on various occasions, and direct propaganda aimed at discrediting Bulgarian politicians and policies. Nevertheless, a March 2015 public opinion poll concluded that "Bulgarians still like Russia, but do not believe that it could be their model for 
development and provide more guarantees for prosperity and security than the EU and NATO membership." "According to the study, with the accession of Crimea and its actions in Eastern Ukraine, the negative attitudes towards Russia increased four times more (by 30 percent) than the positive ones ( 7 percent). The main social groups, in which Kremlin worsened its image, are the residents of the capital and, most of all, among the 18-30 year-olds, while the elderly over 60 years provide the core of the support for Russia's policies. The problem is structural and will, obviously, continue to exist, at least until the door for Russia to Europe through the Balkans is not completely regulated under EU norms.

The ongoing migration crisis adds new shades to the picture of security perceptions of Bulgarians. In 2012, the refugees were unknown or misunderstood by most Bulgarians, or seen as a potential source of criminality and/or contagion. Three years later, 63 percent of the Bulgarians see the migrants as a source of national security threat. The majority supports strong restrictive measures, which institutions are expected to apply, while sociologists underline the risk of strengthening extremist and nationalist reactions. Expectedly, the Bulgarians do not want to spend money from the budget for refugees, and this measure is the least popular (with a support of about 27 percent). The stereotype is that mainly economic migrants cross the territory of Bulgaria on their way to "the rich Europe," and those who remain in the country are not particularly willing to integrate and, thus, are a burden on the state. ${ }^{10}$

In summary, the classical security questions, centred on guarantees for attributes of the state as territorial integrity, sovereignty, and independence, are important for the Bulgarian security discourse but do not correspond to the insecurity agenda of the society. The public is interested mostly in the issues of governance, integrity and legal order. Even on migration, the public concerns are mostly about the capacity of institutions to perform their duties. This perspective signals that despite the growing international chaos and immediate threats to Europe, putting the home affairs in order continues to be a dominant priority for the Bulgarians.

The brief examination in this section is important for introducing the reader to the particular 'transitional' context in which the citizens of Bulgaria perceive any and all of the developments in and around the country that may have security implications. Policy making, on the other hand, needs much more solid evidence related to perceptions, requirements, and priorities, and thus make the security policy adequate and relevant to the needs of the society.

The EvoCS project aims to contribute to the European-wide discourse, offering a detailed overview of security perceptions in different regions of Europe. A better understanding of these concerns is seen as vital to a more effective and representative priority setting in the European security policy-making. 


\section{On the Study's Methodology}

The authors of this study applied the methodology of the project EvoCS ('The Evolving Concept of Security: A critical evaluation across four dimensions'), briefly presented below to make this paper self-contained. For a more comprehensive presentation refer to the EvoCS analytical framework. ${ }^{11}$

The project, as implied by the title, is centred on 'security concepts,' involving five different dimensions. These dimensions are their core values, the actors involved, the types of security challenges (risks, threats and hazards) affecting the core values; the levels at which security is protected; and the ethical and human rights issues which appear in this process. The dimensions together form a country's concept of security at a specific moment in time.

The EvoCS consortium analysed the 'concepts' for a total of 12 countries and produced four regional case studies, outlining differences and similarities across regions, and making conclusions and policy-relevant recommendations: West-Mediterranean EU (Italy, Malta, Spain); Eastern EU Boarder (Poland, Hungary, Lithuania); NorthWest EU (United Kingdom, Netherlands, France); and South-Eastern Europe (Bulgaria, Serbia, Turkey).

To capture different perspectives, and following a detailed methodological guidance, EvoCS researchers collected and processed (coded) information contained in six types of sources: (1) government policy documents (e.g. national security strategies); (2) parliamentary publications (mostly transcripts of debates); (3) academic publications; (4) newspaper articles; (5) private sector publications (e.g. positions of employers' association); and (6) NGO publications. When processing each piece, the researchers extracted information regarding the five dimensions of the 'concept.'

In the case of Bulgaria, a total of 333 pieces of information were analysed. ${ }^{12}$ The results obtained were complemented with qualitative analysis of the security context in South-Eastern Europe by experts, who took part in a regional workshop, held in January 2015 in Sofia. ${ }^{13}$

\section{Core values}

Core values refer to the various aspects of life that actors involved in the political discourse seek to make secure. These aspects are:

1. Physical safety and security

2. Territorial integrity and security

3. Environmental and ecological security

4. Social stability and security

5. Cultural identity and security 
6. Political stability and security

7. Economic prosperity

8. Information and cyber security.

\section{Actors and levels}

The next dimension deals with twelve categories of actors from the public security discourse, whose role may vary from addressor via subject or object to addressee. They can also act on different political levels, i.e. provincial, national or international.

\section{Ethics and Human Rights}

This is taken into consideration in the security construct, as human rights and security are two of the building blocks of the European system. For instance, the European Union (security) strategies are founded upon and targeted to the promotion and the protection of human rights. Fundamental rights can only be enjoyed in a secure, enabling environment.

\section{Security Challenges}

'Security challenges' were the core dimensions of the concepts, analysed in a combined manner under one header: threats, hazards and risks. As EvoCS is looking at perceptions, it was not the actors' accurate use of terms that was sought rather than their thinking of a particular problem.

\section{Results for Bulgaria}

From a distance Bulgaria is often seen as a corner at the far end of the continent next to the Orient and Russia's blizkoe zarubezhie - an exotic political marsh plagued by corruption; a place of rich nature but poor governance; a destination for low cost tourism but also of low salaries, suffering from a continuous brain-drain and "exporting" pick-pocketers of the Roma minority. At the same time, the issue of the Bulgarian immigrants working in the UK was turned into a political tide against the EU acquis communautaire as concerned the terms of free movement of workers. Next to that, European politicians and media have only rarely recognised Bulgaria's success in maintaining macroeconomic stability when countries in the neighbourhood have been collapsing. Instead, Bulgaria is frequently reminded of Vladimir Chizhov's 14 "off the record" provocation "You are our Trojan Horse in the EU," negligently omitting the end of his sentence: "...in a good way.","

No doubt, the picture of today's Bulgaria is so colourful and deformed that outside observers may qualify it as a disappointing abstraction. Curiously, many Bulgarians would agree. The key problem is that for 25 years the Bulgarians have made a lot to transform the country's political system and its economy, to contribute to a common 
or allied foreign policy, and to develop and strengthen the civil society. However, the democratic deficit is as big, as inefficient and corrupt the governments and the administration have been. Societal progress is so slow that people simply do not notice it. No one would dare to determine Bulgarian transition as successful - the people expected much more. All this creates a specific environment for examining the contemporary security of Bulgaria.

\section{Characterisation of the Core Values}

According to the EvoCS preliminary research findings, ${ }^{16}$ various actors in the Bulgarian security discourse attach the greatest degree of salience to political stability and security, followed by economic prosperity and security, and social stability and security (see Figure 1). In order to understand why such a combination dominates over traditional Balkan concerns such as territorial integrity, the study looks for what makes individuals and society so insecure despite the country's membership in NATO since April 2004 and in the EU since January 2007.

Political stability/instability, economic prosperity/stagnation and social stability/ fluctuation are jointly determined. In the case of Bulgaria, oligarchic looting of national assets and the functioning of the political system as a façade hiding weakness and inability to govern in the public interest marked a trend towards de-modernisation. After 25 years of transition, marked by the electoral preference's swaying from the former Communist Party, via the Saviour archetype (the party of former Tsar Simeon II won the 2001 general election and Simeon II was elected prime-minister after he promised to solve Bulgaria's problems in 800 days) to the Strong Hand character (former police general Boyko Borisov is serving his second mandate as a prime-minister); the lack of institutional capacity and will to manage the social imbalances on all sides of the political spectrum; corrupt administration, and economic emigration combined created an environment, characterised by a sense of overall insecurity.

The causal link among the three core values is exemplified by the observation that any political instability ${ }^{17}$ immediately leads to worsening of the financial situation (in 2014, Bulgaria had the second highest increase of budget deficit in the EU, after Cyprus) that is reflected in only tiny social status growth (23\% of Bulgarians live under the poverty bar). According to a Harvard study, "One strong argument underlying this relationship is based upon the effects of uncertainty on productive economic decisions, such [as] investment, production or labour supply. A high propensity of a change of government is associated with uncertainty about the new policies of a potential new government; risk-averse economic agents may hesitate to 


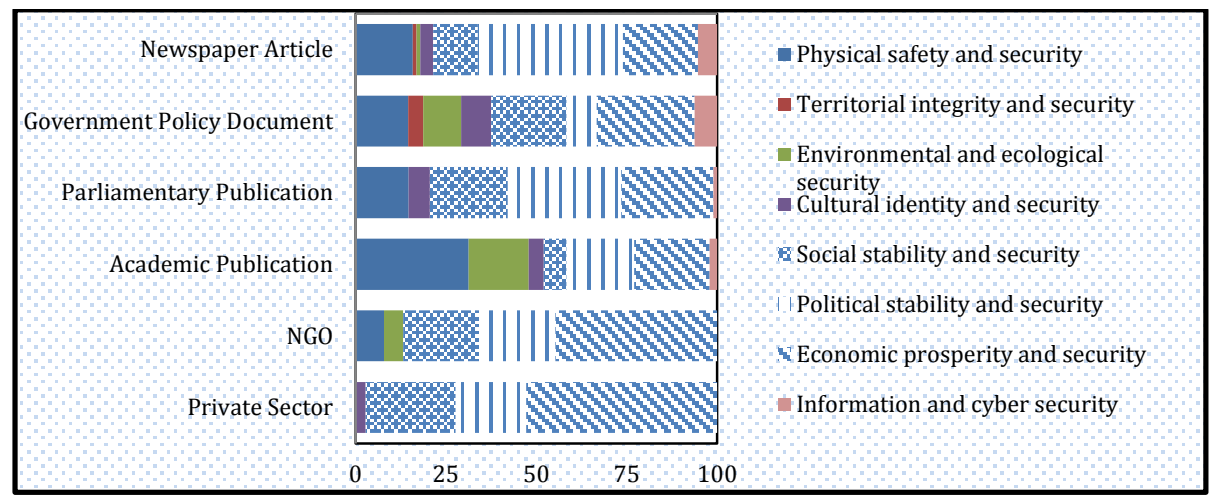

Figure 1: The most salient core values per source. Who talks about what? ${ }^{18}$

take economic initiatives or may 'exit' the economy, by investing abroad. Conversely, foreign investors prefer a stable political environment, with less policy uncertainty and less uncertainty about property rights."19

The impact of the political stability on security perceptions is regarded in Bulgaria as the highest under the influence of three factors: 'traditional' respect to the government (inherited from the communist years) as 'a source of everything,' the relatively high percentage of the population that depends on the political will for their social survival, and the overall fatigue from a utterly prolonged transition. In the context of the legacy paradigm, political stability and social security and equality have been perceived as the most prominent achievements of the communist era that had to be preserved. Accordingly, the democratic process overall, and the political parties and politicians during the transition have been judged primarily on the basis of their views and actions to protect the abovementioned achievements. Thus, politics was reduced to a clash between those that maintain political stability and others that challenge it.

From a social status point of view, the decline in the standard of living, the emergence of mass poverty and high unemployment rates are seen by the authors ${ }^{20}$ as the most sensitive failure of democratic governance, market economy and, since 2007, the membership in the EU. In a period of only six years (1992-97) the financial system collapsed twice and many lost all their savings. Ironically, in both cases it was the ruling party of former communists that caused enormous suffering. A structural effect of these political failures was the dramatic rise of social outsiders. Millions of people of all generations lost their middle class status. In theory, every day citizens enjoy thousands of choices, but in practice they do not have any. Logically, fewer people vote in recent years (voter turnout falling below $50 \%$ at the latest parliamentary elections), ${ }^{21}$ and among those who steadily do not participate in the elections are 
just those marginalised - the poor and the unemployed. Even the EU membership did not change the social map of Bulgaria significantly due to the continued effects of the gap between the reform agenda and the short- and mid-term expectations of citizens. $^{22}$

The transition paradigm encompassed all political, economic and social demands. In 1989-1997, the transition was viewed only as democratisation and marketisation. Democratisation was seen exclusively as the opposite to authoritarianism. Transition towards market economy followed the principle of 'reduced role of the state,' assuming that that is bound to increase economic efficiency. After a corrupt and strategically very chaotic mass privatisation, Bulgaria continued to live in an environment of continuous reforms. This created a sense of an unfinished transition, with the main consequences being the growing gap between public expectations and the elite's agenda, more protests and less political activity, low confidence in politicians and institutions and a sense of discontent.

The impact of the economic prosperity core value on security is very controversial. The most popular questions (even recently) in this respect are: Why our economy develops so slowly and why we fail to reduce the distance to the developed European countries? Is this due to the misguided policies of the past 25 years or to the starting base? (which was very low, regardless of some nostalgic views). Despite starting from a relatively low level, Bulgaria did not achieve an economic breakthrough. There was a period of faster development between 2001 and 2008, with a growth rate of $6 \%$ in two of those years, and real GDP growth of $51 \%$ - way above the average for the EU. At the same time, GDP in purchasing power parity increased from $40 \%$ to $47 \%$ as compared to the average level in the EU. A positive reading of these numbers was that Bulgarian economy was growing faster than the average for developed countries. The downside reading was that the achievements were not sufficient to allow Bulgaria to overtake any other member of the European Union. ${ }^{23}$

The impact of the social stability on security of Bulgaria is viewed through the wider and growing social (in) equality. The relative difference in income between the richest and the poorest $20 \%$ of the population in the country is among the highest in the EU. In addition, in the period 2001-2008 it grew by over $84 \%$. The number of people at risk of poverty or social exclusion in Bulgaria is the highest in the EU. ${ }^{24}$ From the perspective of social equality, Bulgaria is a state of deprivations, resulting from the processes of transition, privatisation, fraud, erroneous economic ideas, the wars in Yugoslavia, pension reform, financial crisis, political populism, corruption, poor governance, oligarchic relations, the crisis in Ukraine, etc.

In conclusion, the three most salient core values in the initial EvoCS study indicate that the country's recent security concerns are rooted in the domestic developments, 
rather than in the external environment. The 'enemy from within' is the combination of democratic deficit, poor governance and lack of trust in the institutional ability to regulate the social relationships in favour of the ordinary citizens.

\section{The Core Values in the Security Context}

As already underlined, a serious gap exists between the political elite's agenda and societal demands in Bulgaria. The breach is not only in the political, economic and social areas, but in security as well. Mistrust in institutions, including those from the security sector, is reflected in a thought-provoking discrepancy between public threat perceptions and the institutional documents on security. Institutions (National Security Agency, MoD, MoI) used to emphasise international terrorism as a security threat even before the terrorist act in Burgas (18 July 2012). However, for the society, the essential threats have always been those that could lead to political instability, financial collapse and further social decline. Recently, the two perceptions were brought closer by the growing migration pressure from the Arabian-African arc of instability. With the 'help' of incapable institutions and due to concerns voiced by radicalised politicians, the Bulgarians started to think of the migrants first of all as potential terrorists. As a result, a $30 \mathrm{~km}$ long wire fence along the border with Turkey was built in order to limit the number of illegal migrants without serious media and public opposition.

A similar discrepancy is seen when threats to the political stability are discussed. According to a report by the then Minister of Interior, ${ }^{25}$ issued in 2013, the main source of political insecurity was the civil protest, protesters being divided into two categories: 'spontaneous protesters,' seeking change in the government, and 'motivated protesters,' whose number was growing, because their suspected organisers pursued political goals. In contrast, EvoCS sources show that people feel insecure, in the political aspect, as a consequence of long lasting political confrontation, lack of essential reforms in critical sectors, and political corruption in all forms throughout the political establishment and institutions. Those have led to division, hatred and tensions in society, with their cumulative effect being a stable negative attitude toward political parties, politics, and politicians. Ignoring the rules of political competition and involving institutions in the process of political confrontation, this further caused a serious decline in the credibility of security sector institutions. An impressive illustration of the consequences of such lasting distrust is Ivan Krastev's observation that the Bulgarian public space is full of compromising documents, recordings and rumours: "The totalitarian utopia of people spying for the government is progressively replaced by a utopia of people spying on the government." ${ }^{26}$ Obviously, trust can be destroyed from both sides. The problem was recognised in the 2014 annual report of the Ministry of Defence on the state of defence and the armed forces that stated: "In this regard, issues of concern are the attempts to manipulate public opinion through 
disinformation, propaganda campaigns, media manipulation, use of social networks for disinformation, attempts by populist party leaders to manipulate groups of voters in order to cause a confusion among the population, and others." ${ }^{27}$

The economic aspect of security is deeply rooted in public perceptions as people are used to think "it would be good for me only if the state is in a good shape." Notably, the period after the financial collapse of 1996-97 (with the socialists in power) has been the longest one of positive development in terms of GDP growth in the history of Bulgaria since 1878. In addition, the extremely restrictive manner of managing the public finances during the international financial crisis that hit Bulgaria in 2009-2013 did not shake the macro parameters seriously. But while budgetary discipline was sustained, many companies on the market went bankrupt and unemployment and poverty rose.

There are three main factors that make the Bulgarians extremely sensitive, suspicious and frustrated when it comes to economic aspects of security. First is the sense of deindustrialisation of the country. Despite that the current GDP is almost twice the highest one during communism (\$28.5 in 1987 against over \$54 bln in 2013 in purchasing power parity), ${ }^{28}$ people still believe that democracy and market economy came at the expense of closing 'the symbols of Bulgarian heavy industry.' Industrialisation was the pearl of the communist platform. However, people do not know or do not want to know anything about the competitiveness of those Soviet-era technologies. The abolishment of the industrial assets did not change the life of hundreds of thousands of people for the better.

The second factor is the belief of the public that mass privatisation during the 1990s was totally corrupt and party driven, and strongly influenced by the former security apparatus. Various privatisation schemes were carried out in morally outrageous ways. But the privatisation was not illegal. According to Krasen Stanchev, "Quite the contrary: the most foolish and inappropriate privatisation approaches and procedures were in strict compliance of what was stipulated in the Privatisation Law (changed 29 times between 1992 and 2004)." 29 Bulgarians relate economy with security so strongly because the most visible figures that benefited from privatisation were former regime nomenclature, organised criminals, former sportsmen on behalf of the former security services, and foreign investors with very dubious sources of capital. The people felt cheated, robbed and socially disqualified.

The third factor is the collapse of the agriculture sector during the transitional period. Within the Council for Mutual Economic Assistance of the former socialist countries Bulgaria was famous with agricultural production and canned foods. The sectorial reform was accompanied by return of once nationalised land to the original owners or their successors and depopulation of villages, which caused a complete collapse of 
the sector in only two years (1992-1993). In recent years the agricultural sector generated $5-7 \%$ of the GDP. It is one of the sectors that have a positive export trade balance, generated from the export of cereal products, while vegetables and fruits are mostly imported. However, the sense of most of the Bulgarians is that the country has lost a significant component of the national economic capacity. Relatively high prices of imported and domestic food products put food in second place in household expenditures, after heating and electricity.

\section{Security Challenges and Threats, Political Actors, Levels and Ethics \& Human Rights}

In the case of Bulgaria, institutional statements on security challenges and threats and EvoCS results differ considerably. Institutions list "existing and emerging new sources of tension as the crisis in Ukraine; outstanding security issues in the Western Balkans; on-going conflicts in Afghanistan, the Middle East and North Africa; asymmetric threats and major transnational terrorism; proliferation of weapons of mass destruction; the increase in military potentials; globalisation and easy access to modern information technology; organized crime; illicit trafficking of people, weapons and drugs; cyber threats; demographic, environmental and energy problems; technical risks and natural disasters and others." 30 The EvoCS preliminary research findings, however, have identified quite a different list of issues and priorities. ${ }^{31}$ The results of the coding exercise could be read as "people say, we lack security." "32 It is not so much about the attributes of the state as independence, sovereignty and territorial integrity, but security in the political-social domain where challenges and vulnerabilities shape peoples' demands for security and progress. It is not about enemies and armed forces, but about high level corruption, organised crime, administrative fraud, wide-spread petty crime - all covered by ineffective justice and law enforcement sector that facilitates penetration of foreign interests and allows massive fraud as in the recent case of Corporate Trade Bank (CTB).

The threat perception gap between the institutional security discourse and the "people say, we lack security" speaks of the character of the Bulgarian nation. Michael Minkov, co-author and follower of Geert Hofstede, ${ }^{33}$ believes that the overall feeling of insecurity stems from the high and constant stress the nation has been exposed to during the communist dictatorship as well as during the transition. ${ }^{34}$ Stepping on the method of Hofstede/Minkov, at least four characteristics should be singled out that contribute to the chronic frustration and the feeling of insecurity of the Bulgarians:

Bulgarians feel distanced from the real power. The belief is that their ability to influence government policy is very limited. The democratic process, as it is, does not change their lives. The sense of socio-political distance and insignificance is amplified by the fact of unacceptably high social inequality. As a result, political activity is 
visibly reduced, the number of political parties-mayflies increases, and populism and nationalism spread.

The nation strives to avoid uncertainty. The dominant socio-political factor for this cultural dimension is the prolonged transition from extremely stable, secure and equalised society through chaos and two internal collapses towards a very shaky internal and international situation at present. According to the latest Eurostat survey on quality of life, the Bulgarians are the least satisfied nation in Europe. ${ }^{35}$

Most people are short- to mid-term oriented. People prefer to get a symbolic increase of pensions now, than to see the government investing their money in something that will bring significant results after a decade. After 25 years of tectonic post-communist changes, they prefer the status quo and evolutionary developments to radical reforms aiming at high future benefits.

Bulgarians are collectivists by tradition, but in a specific manner. Collectivism is about the 'close circle' - family, relatives, colleagues. Everything else - town, society, state, nation, allies is external and thus less or not important. On the other hand, when outside their 'close circle,' individualism dominates the ability of Bulgarians to work in teams.

The above factors are reflected in the list of threats, risks and challenges, as identified by the EvoCS' findings.

Corruption is turning into the main destructive factor in all aspects of life. The threat of "state capture" is real. The 2014 report of the Centre for the Study of Democracy has identified "...the highest levels of participation of Bulgarians in corrupted deals for the past 15 years. On average, 158000 corrupt transactions per month have been registered in 2014. ${ }^{36}$ Political corruption is replacing petty bribery both as the dominant concern and as the cause of most social and economic damages. Its scope and viability generated intensive public protests and strong reactions from EU and the US. Political parties, executives at ministerial and agency level and local leadership are the key players. One can recall the cases of Mr. Delyan Peevski (MP and alleged shadow owner of numerous businesses, including media), who in June 2013 was appointed as chief of the National Security Agency, ${ }^{37}$ the failure of Ponzi-scheme Corporate Trade Bank (BGN 4.2 bln out of its total assets of BGN 6.6 bln turned out to be toxic), the saga of the South Stream pipeline, etc. These examples illustrate how high level corruption turns into a national security threat. According to another CSD report, the political parties" "political investments" (vote buying and control of voters) has increased from $9-9.5 \%$ in 2009 to about $12-13 \%$ in $2014 .^{38}$ The key actors are bundled with national and local oligarchs up to a degree, in which any national interest can be sacrificed in the name of personal, group or party interests. According to the same report, "...the capture of the state by private interests has reached even 
the most powerful law enforcement institutions - prosecutors, financial intelligence and the Central Bank." The international dimension of political corruption is illustrated by the adoption of specific legislation in the interest of Gazprom during the coalition government of Plamen Oresharski (2013-2014).

At the same time, at social level, more often than not corrupt transactions are carried out at the initiative of public administration employees pressuring citizens who need to use their administrative services. Generally, the Bulgarians do not accept corruption, but are forced to participate. This indicates a structural governance problem in the Bulgarian society: corruption poses an additional cost for the use of administrative services for both citizens and businesses. The sharp reaction of the EU by extending the application of the Cooperation and Verification Mechanism shows the common concern with the country's regress in tackling systemic and political corruption. US, Germany, the UK and others provide financial and expert support for strengthening the law enforcement capacity and moving ahead on the issue of judicial reform. US Ambassador Marcie B. Ries stressed in a public speech in 2013 that "...the most challenging and sensitive part of our relationship" was "our work together to combat organized crime and strengthen the rule of law in Bulgaria." ${ }^{39}$ Similarly, then UK Ambassador Jonathan Allen said in 2013 "Bulgarians report widespread corruption across society and Bulgaria remains a high risk country for corruption. We do not see high-level cases being brought against individuals." ${ }^{40}$ The threat is solemn enough because, as Time Magazine bitterly concludes, "For Bulgaria, democracy doesn't necessarily mean prosperity."

Organised crime in Bulgaria is a by-product of the transition. It originates from a combination of various internal and regional factors. Among the former are the collapse of the state in the first half of the 1990s, the plundering of public property, corrupt privatisation, and apparent and hidden collaboration of the police with crime. The main external factors are the embargo against former Yugoslavia and the pressure exerted by criminal networks from Russia, Ukraine and Chechnya, from East Asia and South America to use Bulgarian traffic channels to Western Europe. Some observers believe that the basis of recent organised crime are the contraband channels inherited from the communist regime that have been 'privatised' in the early 1990s with the 'help' of corrupt security officers. Indicative about the nature of the crime is the unique fact that former athletes or high-ranking members of the security forces have led almost all major criminal groups. In the 1990s, the organised crime widely used murder and other forms of violence, perpetrated with virtual impunity. After the gradual legalisation of criminal business, the main focus shifted towards public finances, targeted via corrupt politicians, government officials, prosecutors and judges. The way the Corporate Trade Bank was brought down signals that in Bulgaria organised crime can easily be defined as criminal-in-origin networks, gradually in- 
volving politicians and senior civil servants. These networks have evolved and currently control significant financial resources. Besides, not all of their activities are criminal, what makes it hard to fight them. The good news is that the Bulgarian society seems to have finally grown to taking radical and comprehensive measures for fighting organised crime and corruption. Recently, amendments in the Constitution have been proposed that are expected to improve effectiveness of law enforcement, along with several other legal and organisational measures taking on high-level mafia-type networks and political and administrative fraud.

In the political-economic-social nexus, the issue of Roma integration could be singled out as a slow-burning development with potentially dangerous repercussions for the functioning of the state. According to the latest census in Bulgaria (2011), Roma is the third-largest ethnic group in the country with $4.9 \%$ of the total population, or 325343 people, growing by $0.2 \%$ as compared to 2001 . Efforts to solve Roma problems began with the industrialisation of the country after 1910. Under communism, drastic measures, such as the ban on nomadism and renaming with Bulgarian names have been applied in combination with integration incentives, such as compulsory education, affordable housing, 'reserved seats' in universities and others. The existence of military engineering corps and construction troops equipped Roma men with work skills. All of the above, however, had only limited impact. Now, decades later, the results of the 2011 census are striking - about a fifth of the Roma minority in Bulgaria have not completed primary school, illiterate Roma women are three times more than men. The problem of Roma education affects their employment. In the current economic crisis and persistently high levels of unemployment in some regions of Bulgaria, this problem becomes even more acute - only $19.35 \%$ of all Roma over 15 years of age have jobs. The picture is complicated by three additional problems - poor health (12.6\% of the total Roma population in the country, including children, has some disabilities or a serious chronic disease), poor housing conditions (presence of Roma ghettos where every fourth home is illegally built) and poverty that lead to a dramatic increase in criminal activities among Roma, as well as to a particularly sensitive issue for Bulgarian society - abandoning Roma children in social institutions and selling children abroad. ${ }^{42}$ After the accession of Bulgaria to the EU, the devastating raids of Roma in Europe forced a number of countries and the European Commission to take special measures. At home, a National Strategy of the Republic of Bulgaria for Roma Integration (2012-2020) has been approved by the Parliament. $^{43}$

Emigration and the demographic crisis are other multi-faceted problems deeply affecting society. The case of Bulgaria exhibits most negative demographic trends in the EU, as noted in an official report by the Ministry of Labour and Social Policy. Their combined effect will lead to an average annual decrease of population by 35 
thousand. According to 2012 data, $1.6 \mathrm{mln}$ women are in childbearing age. Their number has decreased by 310 thousand between 1990 and 2010, and by the end of 2015 is expected to fall by another 223 thousand, while in 2030 it will be around 900 thousand. It has been forecasted also that Bulgaria will lose $2.2 \mathrm{mln}$ of its $7.7 \mathrm{mln}$ population by $2060 .^{44}$

Negative demographics are exacerbated by economic emigration. According to the National Statistical Institute, 28727 Bulgarians changed their official address to a country abroad in 2014. The most preferred destination for emigrants is Germany, followed by the United Kingdom, and Spain. ${ }^{45}$ According to Krastev, "mass emigration of people mostly aged between 25 and 50 has dramatically hurt the Bulgarian economy and its political system. Businesses complain about a shortage of qualified labour. Bulgaria's health system is deprived of well-trained nurses who can earn several times more by taking care of a family in London than working in a hospital in Bulgaria. Most of Bulgaria's best high school graduates do not apply to study at Bulgarian universities, thus depriving them of talent: after the Chinese, Bulgarians are now the second biggest foreign student community in Germany." 46

Relations with Russia are a specific challenge for Bulgaria, with its special place in Kremlin's European energy strategy. ${ }^{47}$ It will not be far-fetched to say that Bulgaria's energy system is under the full control of corporate oligarchies in Moscow and in Sofia. The way Kremlin approaches Bulgaria is by proposing a package of multi-billion projects (whose actual price is never publicly known initially) and using the energy oligarchs, socialist party affiliates and media to pressure Bulgarian governments. The Burgas-Alexandroupolis oil pipeline was developed in the early 1990s, and a framework agreement between Russia, Greece, and Bulgaria was signed in Athens in 2007 (17 years later!). The project envisaged almost no benefits for Bulgaria but posed high environmental risks and other liabilities for the Bulgarian Black Sea coast, a popular tourist area. Consequently, Bulgaria's participation in the project was revoked in 2010. Immediately after the collapse of this project, another one- the South Stream gas pipeline - was inked in late 2012. Bulgarian analysts believe that the project has been initiated in a Kremlin attempt to compromise the EU's Third Energy Package (to come into effect the following year). However, according to Ognyan Minchev, “...the most controversial Russian project in Bulgaria is the planned Belene power plant, designed to be the first Russian-technology nuclear site on EU soil. For a decade after 2002, Belene developed as a corrupt and completely illegitimate business project, aimed at producing abundant and expensive electricity in a country with excess capacity and a region of declining electricity demand. As the Bulgarian government terminated the Belene project in early 2012, pro-Russian energy lobbies opened a noisy campaign in favour of the project, which ended up in a referendum on nuclear energy that failed to produce clear results." The doubling and tripling of 
electricity bills in January 2013, that later led to the government's resignation, is widely believed to have been an orchestrated manipulation aimed at provoking open public discontent and street protests. Minchev rightly suggested: "The Bulgarian crisis might prove a case study for destabilisation in Eastern Europe." 48

Russia's influence on the economy and, through it, on the political system and foreign policy of Bulgaria, has been built up during the Cold War and modified during the transition. Main transmitters of influence are the former communist party, renamed as Bulgarian Socialist Party, and the old cadres of the special services and diplomatic corps that empower their pawns in key sectors of the economy. The second circle, created to influence the public opinion, includes bought or bribed media, sponsored foundations, NGOs and academics. The model that works successfully and has been tried in a different context, was recently "enriched" by funding small parties, that managed to achieve representation in Parliament ${ }^{49}$ (thus offsetting the current decline of the Socialist Party), arrogant diplomatic pressure on various occasions, and direct propaganda aimed at discrediting Bulgarian politicians and policies. The problem is structural and will continue to exist, at least until the door for Russia to Europe through the Balkans is not closed.

Delayed reforms in the security and law enforcement sector are regarded by society as a serious challenge and part of the problem. The plan for defence reform 20002004 is the only realised plan within the sector. Recently, a package of four laws to put in order the national security governance and to regulate military and civilian intelligence and the government's guard service have been passed at first reading in the Parliament. The positive element is that the security services will finally function on a legislative base, but the prospective acts contain very few "reforms." Even stronger, the public demands reforms of the judicial system, in order to protect prosecutors and judges from external (corrupt and political) influences and to make overall law enforcement effective. It is still to be seen whether such far-reaching reforms will require constitutional amendments and, if so, could there be a qualified parliamentarian majority to adopt them.

\section{Current Trends}

Bulgarians live in uncertain times. Uncertainty is both national and external, with many profound socio-psychological effects that may cause U-turns in the country's behaviour on security issues completely. However, the current economic stress impacts everyday life, consumption has shrunk, public expenditures are cut. The state and the people have tightened their belts, obviously frightened for the future. As Ivan Krastev noted, Bulgaria still manages to avoid economic and social breakdown that has destabilised several European countries. Economy is slowly recovering from the 
crisis, there are no mass street protests, and the bank system is stable (except for CTB). ${ }^{50}$

The EvoCS South East European regional workshop ${ }^{51}$ correctly reflects the current public and political focus on stability in political, economic and social domains in Bulgaria. This trend will continue to dominate, especially if tensions with Russia deescalate. Neither the current crisis in Macedonia, nor the migration pressure can take a priority place for a longer period of time.

In the political domain, the core issue of concern is the government's stability and the sustainability of the pro-reform parliamentary majority. The centre-right coalition is stable so far, but tough reforms are still ahead - judicial reform, healthcare optimisation, social security system reform to cope with a serious deficit, security sector reform and others. The role of the pro-Russian forces is seriously limited. However, Kremlin is ambitious to maintain its presence and role in the Balkans (Moscow's nervous reaction on the recent crisis in Macedonia illustrates how strong their interest is ${ }^{52}$ ) and further steps may activate Russian advocates.

In the economic domain, the core question is how to maintain macroeconomic stability and at the same time find resources to stimulate business activities and finance social programmes. International experts believe that "...the country will remain on a sustainable fiscal trajectory due in part to its exceptionally low public load." ${ }^{, 53}$ A serious financial risk factor is the perspective of Greece, as there are several Greekowned banks in Bulgaria, several thousand companies and considerable trade exchange. Real GDP growth will depend on the political stability, the ability of the government to attract foreign direct investments again, to increase further the effective use of EU funding and provide internal resource for investments. The experts believe that a growth of $1-2 \%$ for the next $2-3$ years is a realistic perspective. ${ }^{54}$

In the social domain corruption and organised crime will continue to present the most serious problems with impact on security. The good news is that there is a strong and sustainable, both external and internal, pressure on executive, legislative and judicial powers finally to achieve significant results.

\section{Conclusions for the Bulgarian Country Profile}

At institutional level, which is the subject of this section, Bulgaria shares the European institutional threat perception within the comprehensive approach to security. At public level (as reflected by media and experts), Bulgarian society is mostly inward focused - on corruption and political populism, organised crime and massive petty crime; political and institutional stability. As the civil society is still in the process of consolidation, the government is seen as an overwhelmed and overstretched security actor (see Figure 2). 
Generally, as a state, society and culture, Bulgaria is very vulnerable. Its capacity to recover and develop after political, financial and security shocks has been tested with limited success, but has not been significantly strengthened. Fragility is still tackled not by strategy, but by expanding the scope of security far beyond the capacity of the government to manage various issues. Bulgarian society is systematically problematizing the challenges and threats discussed above, but the authorities still fail to make them 'political problems of security' as they do not see rational solutions. Instead, governments have become champions of drafting strategies that no one can or cares to follow.

\section{Policy Recommendations}

Security policymaking is becoming more complex with the development of an EU identity in the security domain. It is worth reminding that, on the one hand, as stressed in art. 3a of the Treaty of Lisbon the EU “......shall respect the equality of Member States before the Treaties as well as their national identities, inherent in their fundamental structures, political and constitutional, inclusive of regional and local self-government. It shall respect their essential State functions, including ensuring the territorial integrity of the State, maintaining law and order and safeguarding national security. In particular, national security remains the sole responsibility of each Member State." ${ }^{, 55}$ But the Member States' lead in security confronts a "more connected, contested and complex world" in the wording of the EU Strategic Review. $^{56}$

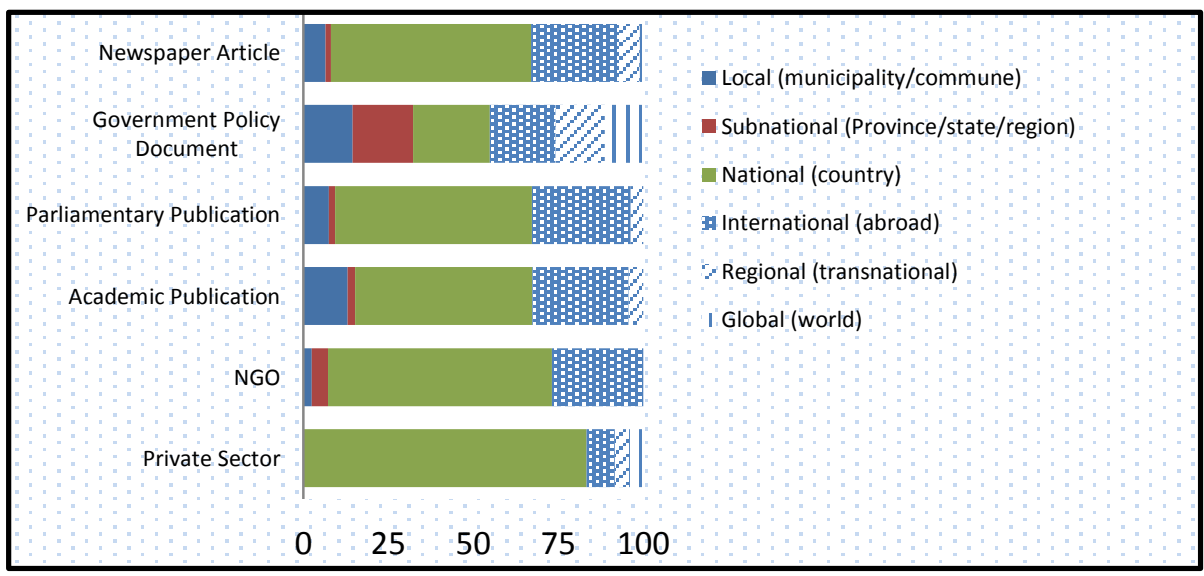

Figure 2: The most salient levels of action per source type. 
So, it seems relevant for Bulgaria to highlight a few findings, based on the results of the coding, SEE workshop exchanges and literature review with the aim to contribute to a more effective policy-making at the national level and within the EU:

Table 1: Comparison across security challenges.

EvoCS results

(Security concept snap-shot of 2014)
EU Agenda on Security ${ }^{5}$

(March 2015)
EU Strategic Review

(June 2015)

\begin{tabular}{|c|c|c|}
\hline Corruption & Terrorism & Arc of instability \\
\hline Organised crime & Organised crime & \multirow{4}{*}{$\begin{array}{l}\text { No respect for basic ten- } \\
\text { ets of international law } \\
\text { Changes of regional law } \\
\text { in the Middle East }\end{array}$} \\
\hline Emigration and demographic crisis & Cybercrime & \\
\hline Relations with Russia & & \\
\hline $\begin{array}{l}\text { Delayed reforms in the security and } \\
\text { law enforcement sector }\end{array}$ & & \\
\hline
\end{tabular}

- Bulgarian uniqueness: Bulgarian political discourse is the only one out of the twelve examined, which is dominated by the "political stability and security" core value. This implies that hard security issues might suffer from being below the (public) radar at the expense of otherwise plausible attempts to 'clean the house.'

- Legitimacy: As mentioned previously, there is a gap between popular and official threat perceptions. In the meantime, Bulgaria's future strategic documents in the field of security need to strike a balance between EU-wide policies and national priorities.

- Inward focus vs EU global posture: Against an external environment, promptly outlined by the EU Strategic Review and forming the basis of a future EU global strategy to steer the Union's external action, efforts to depart from this peculiar inwardness should be made to niche-place the Bulgarian foreign service and boost the EU capacity in the field of foreign and security policy-making.

- National and local: The Bulgarian government is an overstretched actor. Thus, encouraging and empowering the local level of action, plus undertaking a multi-stakeholder approach to security, involving more closely NGOs and the private sector, may be beneficial for improving the security landscape in the country. 
- Human rights: Human rights' issues are reflected in the coded documents; however this does not mean that at current human rights and ethical values are properly taken into account.

\section{Conclusion}

The study results on Bulgaria indicate that there is a conflict (discrepancy) between the major security concerns of the people and their expectations how these concerns could be alleviated. On one hand, the prevailing concerns relate to governance - in the political and social spheres, as well as the inability to reverse the tide of corruption in the country. On the other hand, the majority continues to see the government as the actor that is expected to resolve all the underlying problems. As a result, we witness a double disconnect - between the official Bulgarian security discourse and societal perceptions of security challenges, on the one hand, and between challenges identified in EU security strategies and challenges faced by Bulgaria, on the other. Street protests in the summer of 2013 and 2014 demonstrated that civil society needs to and can turn into the key player in enhancing governance. This paper has a more modest ambition in finding ways forward, and suggests revitalisation of the security discourse - a small but potentially decisive step towards increasing policy legitimacy.

\section{Acknowledgement}

The research leading to these results has received funding from the European Community's Seventh Framework Programme (FP7/2007-2013) under Grant Agreement $\mathrm{n}^{\circ} 605142$. We thank the EvoCS project partners and the anonymous reviewers of this paper for contributing to the discussions. Only the authors' views are reflected, the Commission and the Project are not liable for any use that may be made of the information contained therein.

\section{Notes}

1 Ivan Krastev, "The transition started and ends as a crisis," an interview for 24 Hours daily, 2 October 2007, available in Bulgarian at http://www.cls-sofia.org/download.php?id=84.

2 Daniel Kaddik, Director of the South Eastern Europe project, Frederich Naumann Foundation, "In Bulgaria there is a serious deficit of democracy," available in the Bulgarian language at http://www.bgnes.com/bez-filtyr/bez-filtyr/4371044/.

3 This issue is examined in more detail in the next section.

4 Survey on Income and Living Conditions - Poverty and Social Inclusion Indicators, National Statistics Institute, 15 October 2015), available at www.nsi.bg/en/content/ 8293/\%D0\%BC\%D0\%B5\%D1\%82\%D0\%B0\%D0\%B4\%D0\%B0\%D0\%BD\%D0\%BD\%D $0 \% \mathrm{~B} 8 /$ poverty-and-social-inclusion-indicators.

5 The 'poverty line' should guarantee that a person meets the minimum basic needs of food and non-food goods and services. 
6 Data from the Ministry of Finance published at http://www.vesti.bg/bulgaria/minimalnatazaplata-shte-raste-ot-2016-g-6034972 and the bulletin of UniCreditBulbank, October 2015.

7 According to the Prime Minister's speech at economic forum, 22 June 2015.

8 Anti-corruption Policies Against State Capture (Sofia: Center for the Study of Democracy, 2014). Available in the Bulgarian language at www.csd.bg/index.php?id=275.

9 Alfa Research, Bulgarian Foreign Policy, the Conflict "Russia - Ukraine," and the National Security, February-March 2015, available in Bulgarian at http://alpharesearch.bg/userfiles/ file/0215_Public_Opinion_AR_present.pdf.

10 Data from a survey presented by the sociologist Boryana Dimitrova at a press conference, called by the member of the European Parliament Svetoslav Malinov, 28 September 2015.

11 Tim Swejis, Joshua Polchar, Boaz Manger, Willem Oosterveld and Laurin Nabuko Hainy, "Assessing Evolving Concepts of Security," EvoCS Deliverable 3.1, 20 February 2015, http://dx.doi.org/10.11610/evocs.d31.

12 For a more detailed description of the reports analysed, see Miloš Jovanović, Valeri Ratchev, Todor Tagarev, Vesselin Petkov, Antonia Todorova and Pinar Elman, "Case Study on South-Eastern Europe," EvoCS Deliverable D8.2, 03 September 2015, available at http://dx.doi.org/10.11610/evocs.d82.

${ }^{13}$ A detailed account of the Workshop is provided in Miloš Jovanović, Vesselin Petkov, Maria Radziejowska, and Antonia Todorova, "Regional Workshop on South-Eastern Europe," EvoCS Deliverable D8.1, 28 February 2015, availa $\neg$ ble at http://dx.doi.org/10.11610/evocs.d81.

14 Permanent Representative, Permanent Mission of the Russian Federation to the European Union.

15 The Ambassador of Russia to the European Union Vladimir Chijov in an interview for the weekly Capital, available in Bulgarian at http://www.capital.bg/politika_i_ikonomika/ bulgaria/2006/11/10/293214_vladimir_chijov_vie_ste_nashiiat_troianski_kon_v_es_v/.

16 Miloš Jovanović, Vesselin Petkov, Maria Radziejowska, and Antonia Todorova, "Regional Workshop on South-Eastern Europe.”

17 "Political instability" is defined as the propensity for change in the executive, either by "constitutional" or "unconstitutional" means. The last two regular government mandates were terminated after public protests, respectively in February 2013 and July 2014.

${ }^{18}$ Figure 1 presents a normalised view of the results obtained from the coding of the 333 pieces of information for Bulgaria, demonstrating the salience attached by the different sources to the various core values.

19 Alberto Alesina, Sule Özler, Nouriel Roubini, and Phillip Swagel, "Political instability and economic growth," Journal of Economic Growth 1, no. 2 (1996): 189-211, available at http://dx.doi.org/10.1007/BF00138862.

20 Similar are the views expressed in discussions, speeches and papers by Ivan Krastev, Ognyan Minchev, the Institute for Market Economics, Open Society and others, who studied the reasons for recent expansion of public protests. These factors are seen also as main reasons for emigration of Bulgarian youth and the high social inequality. In terms of EvoCS coding results, unemployment and poverty are among the highest ranking challenges as regards the social dimension.

${ }^{21}$ Voter turnout data, Central Election Commission, http://results.cik.bg/

22 Ivan Krastev, The Inflexibility Trap: Frustrated Societies, Weak States, and Democracy (Bratislava: UNDP, 2002). 
23 According to Roumen Avramov, a Bulgarian economist and economy historian, available at http://www.mediapool.bg/da-si-nai-bedniyat-v-kluba-na-bogatite-e-mnogo-po-boleznenootkolkoto-da-si-beden-izvan-nego-news218625.html.

24 Stoyan Hristov, Inequality in Bulgaria - Dynamics, Comparative Analysis and Reasons (Sofia: Institute for Market Economics, 2013); available at http://ime.bg/var/images/ Inequality_full_text.pdf. The author of the report points to difficulties in comparing data before and after 2006-2007, when Bulgaria adopted the European methodology for social research (EU-SILC).

25 Current risks and threats to the national security of the Republic of Bulgaria, Report by the Minister of the Interior to the Consultative Council for National Security, 20 November 2013, available in Bulgarian language only at www.mvr.bg/NR/rdonlyres/32924394-C30B4C6E-B0C2-EEBDD103A43E/0/DOKLADKSNS201113FINAL.docx.

26 Ivan Krastev, In Mistrust We Trust: Can Democracy Survive When We Don't Trust Our Leaders? (TED Books, 2013).

27 Ministry of Defence, 2014 Annual Report of the on the State of Defence and the Armed Forces, available at http://www.md.government.bg/bg/doc/drugi/20150327_Doklad_MO_ 2014.pdf (in Bulgarian).

28 Source: The World Bank development indicators, available at http://data.worldbank.org/ country/bulgaria\#cp_wdi.

29 Krasen Stanchev, Bulgarian Economy: What the Politicians Do Not See (Sofia: Institute for Market Economics, 2012), available in Bulgarian at http://ime.bg/bg/articles/ikonomikatana-bylgariya-kakvo-ne-vijdat-politicite/.

30 Quotation from the Government's Annual Report on Defence and Armed Forces (2014), available in Bulgarian at www.md.government.bg/bg/doc/drugi/20150327_Doklad_MO_ 2014.pdf (unofficial translation by the authors).

31 Jovanović, Petkov, Radziejowska, and Todorova, "Regional Workshop on South-Eastern Europe."

32 "Lack" and "security" occupy 1st and 2nd rank, respectively with 65 and 55 hashtags, in Vesselin Petkov's Preliminary Research Findings on Bulgaria.

33 Geert Hofstede and Michael Minkov, Cultures and Organisations: Software of the Mind, 3nd edition (New York: McGraw-Hill USA, 2010).

34 Opinion in the introduction to the Bulgarian translation of the book.

35 See, for example, the map at http://ec.europa.eu/eurostat/statistics-explained/index.php/ Quality_of_life_in_Europe_-_facts_and_views_-_overall_life_satisfaction.

36 Anti-corruption Policies Against State Capture.

37 After the comic promotion of Peevski, tens of thousands of people filled Sofia's main boulevard in mid-2013 to protest. According to opinion polls, fully 70 per cent of the public supported the demonstrators.

38 Center for Study of Democracy, Corruption and Anti-Corruption in Bulgaria (2013-14) (Sofia: CSD, 2014). Available in Bulgarian at www.csd.bg/artShowbg.php?id=17200.

39 Marcie B. Ries, "The U.S.-Bulgaria Partnership - Built on a Foundation of Shared Values," Remarks to the Atlantic Club, 30 January 2013, http://www.atlantic-club.org/index.php? keynote-speech-by-he-marcie-ries-ambassador-of-the-united-states-to-bulgaria.

40 Speech by British Ambassador Jonathan Allen: "Should I be an Optimist or a Pessimist for Bulgaria?" Foreign \& Commonwealth Office, 11 April 2013, available at www.gov.uk/ government/speeches/british-ambassador-jonathan-allen-should-i-be-an-optimist-or-apessimist-for-bulgaria. 
41 Olivier Laurent, "Broken Dreams: The Aftermath of 25 Years of Democracy in Bulgaria," Time Magazine, 10 March 2015. Available at http://time.com/3731816/bulgaria-democracy. Juliana Popova, Integration of Roma Communities in Bulgaria and Romania (OP "Human Resources Development," 2012), available in Bulgarian at http://conf.uni-ruse.bg/bg/docs/ cp12/5.2/5.2-8.pdf.

43 The strategy is available in the Bulgarian language at http://www.nccedi.government.bg/ page.php?category $=125 \& \mathrm{id}=1740$.

44 The 2015 Ageing Report: Economic and budgetary projections for the 28 EU Member States (2013-2060), European Economy 3 (2015), available at http://ec.europa.eu/ economy_finance/publications/european_economy/2015/pdf/ee3_en.pdf.

45 As the report has been quoted by Sega Daily at www.segabg.com/article.php?id=747848.

46 Ivan Krastev's column in The Guardian, Britain's gain is Eastern Europe's brain drain, available at www.theguardian.com/commentisfree/2015/mar/24/britain-east-europe-braindrain-bulgaria.

47 "Energy" is ranked 7th and "Russia" is 12th as hashtags in the EvoCS preliminary research findings on Bulgaria.

48 Ognyan Minchev, Russia's Energy Monopoly Topples the Bulgarian Government. Posted on 4 March 2013 at http:/www.gmfus.org/blog/2013/03/04/russia's-energy-monopolytopples-bulgarian-government.

49 Both "Ataka" and "Patriotic front"- now in Parliament-were born in the city of Burgas, where the Lucoil refinery is extremely influential. Ataka's election campaign started in Moscow and ended in Sofia with Iosif Kobzon's (currently on the EU sanctions list) live show. Both parties plus the socialists are against any sanctions against Russia.

50 Interview for 24 hours newspaper, available in the Bulgarian language at www.24chasa.bg/ Article.asp?ArticleId=736872.

51 Jovanović, Petkov, Radziejowska, and Todorova, "Regional Workshop on South-Eastern Europe."

52 See for example Elena Holodny, "The Kremlin thinks that the massive protests rocking a Balkan nation are an outside job to hurt Russia," Business Insider, 20 May 2015, available at http://www.businessinsider.com/russia-lavrov-macedonia-protests-2015-5.

53 See Bulgaria Country Risk Report, BMI Research, 27 May 2015, available at http://store.bmiresearch.com/bulgaria-country-risk-report.html.

54 The European Bank for Reconstruction and Development forecasts 1-1.5\% growth.

Official Journal of the European Union, Treaty of Lisbon, http://eur-lex.europa.eu/legalcontent/EN/TXT/HTML/?uri=CELEX:12007L/TXT\&from=EN.

56 European Union External Action Service, "The European Union in a changing global environment," available at http://eeas.europa.eu/docs/strategic_review/eu-strategic-review_ strategic_review_en.pdf.

57 European Commission, Communication from the Commission to the European Parliament, the Council, the European Economic and Social Committee and the Committee of the Regions, The European Agenda on Security, available at http://ec.europa.eu/dgs/homeaffairs/e-library/documents/basic-documents/docs/eu_agenda_on_security_en.pdf. 
VALERI RATCHEV is a security analyst at the Centre for Security and Defence Management. He served as Chief of Cabinet of the Minister of Foreign Affairs (2010-2013) and of the Minister of Defence (2009-2010), Ambassador Extraordinary and Plenipotentiary of the Republic of Bulgaria to the Republic of Iraq. Colonel in the reserve, he has served in variety of command and staff positions in Bulgaria's Land Forces. Since the early 1990s he is involved in security and defence policy making both as practitioner and contributor to post-Cold war conceptual developments as Deputy Director of National Security Studies Centre (1994-1998), Deputy Director of the MOD Defence Planning Directorate (1998-2000), Deputy Commandant of the "G.S. Rakovski" Defence and Staff College and Dean of its National Security and Defence Faculty (2000-2005). Mr. Ratchev is among the best known Bulgarian authors in the field of security with main research interests in strategic studies with focus on planning, crisis management and security sector reform.E-mail: ratchevv@yahoo.com

VESSELIN PETKOV combines experience in project management, research and analysis, stakeholder relations and social media. Currently he is the Director for Outreach at Procon Ltd., being responsible for work package management in EU projects. Mr. Petkov is graduate of the Faculty of Law of Sofia University. Member of the DCAF Young Faces Network, in 2004-2011 he was part of the team of the Centre for Southeast European Studies (CSEES) - an NGO actively working to promote Bulgarian membership in NATO and the establishment of a new generation of leaders in security and defence. In March-May 2013 Mr. Petkov was adviser to the Minister of Defence, with responsibilities to construct and lead the work of an Advisory Council on Defence Policy. Most recent peer-reviewed publications by Vesselin Petkov focus on crisis management systems in Eastern and South-Eastern European countries (Albania, Hungary, Latvia and Poland).

E-mail: vesselin.petkov@procon.bg

TODOR TAGAREV is Professor at the Institute of Information and Communication Technologies of the Bulgarian Academy of Sciences and Head of its IT for Security Department and Centre for Security and Defence Management. A security and defence planner combining governmental experience with sound theoretical knowledge and background in cybernetics, complexity, and security studies, he has been specializing in security sector reform and institution building, primarily from organizational management perspective. Prof. Tagarev was defence minister in Bulgaria's Caretaker Government, March-May 2013. He is Editor-in-Chief of Information \& Security: An International Journal and the DCAF series in Security and Defence Management, member of the Editorial Boards of Connections: The Quarterly Journal and the Journal of Defense Management. 